\title{
MODEL PENGENTASAN KEMISKINAN MELALUI KEBIJAKAN PKH DI JAWA TENGAH
}

\author{
${ }^{1}$ Iva Faulana, ${ }^{2}$ Indri Murniawaty \\ 1,2,Program Studi Pendidikan Ekonomi, \\ Universitas Negeri Semarang \\ E-mail: indri@mail.unnes.ac.id
}

\begin{abstract}
Poverty is a major problem faced by all countries including Indonesia. One of the poverty alleviation programs in Indonesia is the Family of Hope Program (PKH). Central Java Province is one of the provinces that has a relatively high number of poor people among the provinces in Indonesia. The purpose of this study is to examine the success of the PKH Program in poverty alleviation efforts in Central Java. The purpose of this study is to describe the implementation of the Family Hope Program (PKH) in poverty alleviation efforts through PKH policies in Central Java Province, starting from the education, health and social welfare components. The theory used in this study is the vicious circle theory of poverty. The method used in this research is descriptive qualitative, with data collection techniques namely observation, interviews, and study documentation. The results of this study indicate that the Family Hope Program (PKH) in Wonosobo Regency, Central Java Province has succeeded in reducing poverty levels in addition to that the implementation of the Family Hope Program (PKH) in Wonosobo Regency has run quite well. But in reality there are still many Beneficiary Families (KPM) who depend on PKH assistance, given that such assistance is only temporary and is more focused on breaking the poverty chain.
\end{abstract}

Keywords: Poverty; Program Keluarga Harapan

Abstrak

Kemiskinan merupakan masalah utama yang dihadapi oleh semua negara termasuk Indonesia. Salah satu program pengentasan kemiskinan di Indonesia adalah Program Keluarga Harapan $(\mathrm{PKH})$. Provinsi Jawa Tengah merupakan salah satu provinsi yang relatif memiliki jumlah penduduk miskin yang cukup tinggi diantara provinsi di Indonesia. Tujuan dari penelitian ini adalah untuk mengkaji keberhasilan Program PKH dalam upaya pengentasan kemiskinan di Jawa Tengah. Tujuan dari penelitian ini adalah mendeskripsikan implementasi Program Keluarga Harapan (PKH) dalam upaya pengentasan kemiskinan melalui kebijakan PKH di Provinsi Jawa Tengah, mulai dari komponen pendidikan, kesehatan, dan kesejahteraan sosial. Teori yang digunakan dalam penelitian ini adalah teori lingkaran setan kemiskinan. Metode yang digunakan dalam peneilitian ini adalah kualitatif deskriptif, dengan teknik pengambilan data yaitu observasi, wawancara,dan studi dokumentasi. Hasil penelitian ini menunjukkan bahwa Program Keluarga Harapan (PKH) di Kabupaten Wonosobo, Provinsi Jawa Tengah telah berhasil menurunkan tingkat kemiskinan selain itu pelaksanaan kegiatan Program Keluarga Harapan (PKH) di Kabupaten Wonosobo telah berjalan cukup baik. Tetapi dalam kenyataanya masih banyak Keluarga Penerima Manfaat (KPM) yang bergantung pada bantuan $\mathrm{PKH}$, mengingat bahwa bantuan tersebut hanya sementara dan lebih terfokus untuk memutus rantai kemiskinan.

Kata kunci : Kemiskinan; Program Keluarga Harapan 


\section{PENDAHULUAN}

Kemiskinan merupakan masalah sosial yang dihadapi oleh semua negara termasuk Indonesia, artinya kemiskinan merupakan masalah utama dan menjadi perhatian semua pihak yang harus segera diatasi. Meskipun dalam permasalahan yang berbeda tidak satupun negara yang mampu mengatasi permasalahan kemiskinan. semua negara di dunia sepakat bahwa kemiskinan merupakan permasalahan sosial kemanusiaan yang menghambat kesejahteraan yang harus dan bisa diatasi dengan baik. kemiskinan menurut Asep Suryahadi (2016:2) merupakan kondisi keterbatasan kemampuan untuk memenuhi kebutuhan hidup secara layak seperti keterbatasan dalam pendapatan, keterampilan, kondisi kesehatan, penguasaan aset ekonomi, maupun akses informasi. Masalah kemiskinan juga ditandai oleh rendahnya mutu kehidupan masyarakat, Embun Suryani (2019:32).

Dampak negatif dari kemiskinan seringkali menimbulkan banyaknya permasalahan sosial, untuk itu bagi pemerintah kemiskinan juga dapat mempengaruhi pembangunan ekonomi suatu negara. Kemiskinan yang tinggi menyebabkan biaya pengeluaran dari pemerintah yang digunakan untuk proses pembangunan ekonomi juga menjadi lebih besar, seiring dengan tingginya angka kemiskinan. Tingginya angka kemiskinan di Indonesia yang didominasi oleh pulau Jawa menunjukkan bahwa program- program penanggulangan kemiskinan selama ini belum bisa mengatasi dan harus segera dievaluasi baik tingkat nasional maupun daerah.

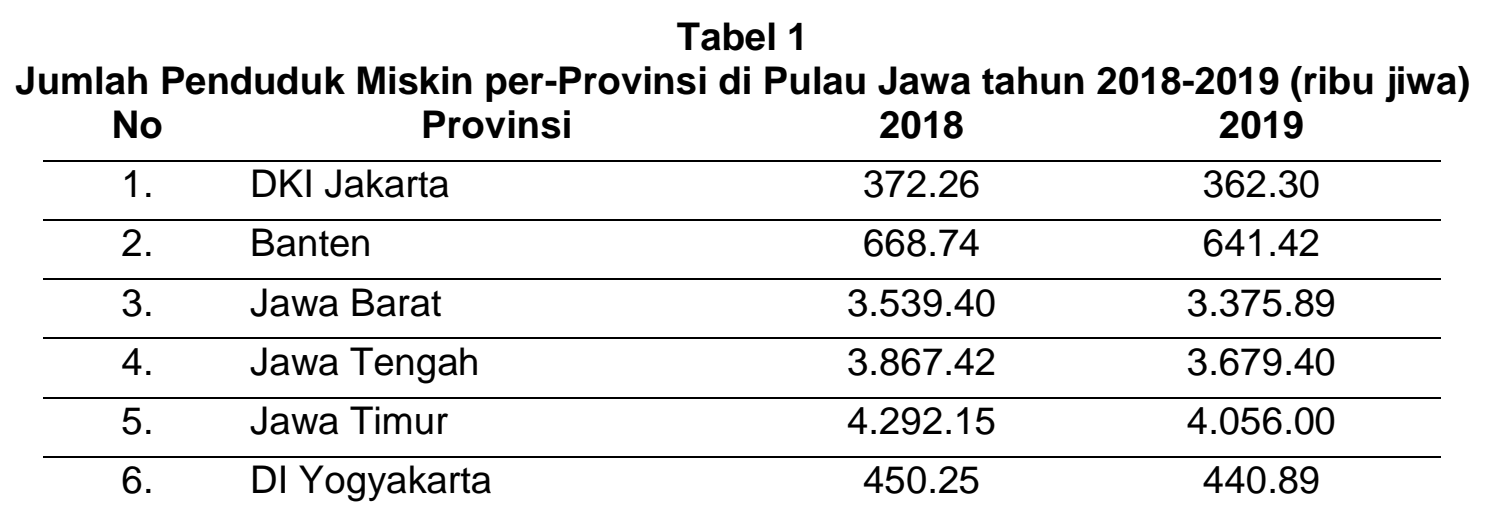

Sumber: BPS, 2019

Berdasarkan data dari Badan Pusat Statistik (BPS) 2018-2019 jumlah kemiskinan di Jawa Tengah sebesar 3.679,42 jiwa, menduduki urutan kedua setelah Jawa Timur dengan jumlah 4.056,00 jiwa. tingginya jumlah penduduk miskin di Jawa Tengah membutuhkan sebuah kebijakan bersama dalam mengelola wilayah pemerintah provinsi dan pusat dengan berfokus pada kabupaten atau kota yang banyak memiliki jumlah penduduk miskin, sehingga permasalahan tersebut dapat segera diatasi. Dengan banyaknya jumlah penduduk miskin di Jawa Tengah membuktikan bahwa masih banyak penduduk yang memiliki tingkat kesenjangan sosial yang tinggi. Tingkat kemiskinan di Jawa Tengah telah membuat pemerintah lebih memperhatikan upaya pengentasan kemiskinan (Puspita 2015). Untuk memahami masalah kemiskinan di Jawa Tengah perlu memperhatikan lokalitas pada masing- masing daerah, diantaranya kriteria kemiskinan, pengumpulan data kemiskinan, penargetan, pemecahan masalah dan upaya pencegahan kemiskinan yang lebih objektif dan tepat sasaran (Rusdarti, 2013).

Untuk mengatasi masalah kemiskinan pemerintah mengeluarkan kebijakan penanggulangan kemiskinan yaitu Program Keluarga Harapan $(\mathrm{PKH})$ dengan tujuan untuk membantu masyarakat miskin memenuhi kebutuhan masyarakat miskin. Selain itu temuan dari Sergei Soares (2007) dalam buku kerja International Poverty Centre mengungkapkan bahwa program bantuan tunai bersyarat atau Conditional Cash Transfer (CCT) dapat membantu mengurangi ketidaksetaraan antar masyarakat untuk memenuhi kebutuhan hidup. Dengan demikian program penanggulangan kemiskinan ini tidak diberikan secara percuma melainkan dengan memenuhi persyaratan yang telah ditentukan oleh pemerintah. Banyak daerah di Jawa 
Tengah yang menerima bantuan PKH, salah satunya yaitu Kabupaten Wonosobo, Jawa Tengah. Ketertarikan peneliti dalam menentukan wilayah di Kabupaten Wonosobo karena Kabuapten Wonosobo merupakan kabupaten yang menyandang sebagai kabupaten termiskin selama lima tahun terakhir dari tahun 2013- 2018. Dalam penelitian ini Kecamatan Kertek, Kabupaten Wonosobo merupakan lokasi yang dijadikan sebagai objek penelitian. Adapun sasaran pelaksanaan $\mathrm{PKH}$ di Kecamatan Kertek sebagian besar penduduknya bermata pencaharian sebagai petani kebun dan buruh serabutan, mengingat bahwa wilayah kecamatan tersebut terletak di lereng Gunung Sindoro yang secara ekonomi masyarakatnya banyak yang kurang mampu, seperti menyekolahkan anak- anak mereka dan kurang memperhatikan kesehatan pada ibu hamil dan balita.

Kemiskinan di Kecamatan Kertek ini membutuhkan penanganan yang tepat, mengingat letak geografisnya yang terletak di lereng gunung dan masih banyak masyarakat yang kurang memperhatikan pentingnya pendidikan, kesehatan dan kesejahteraan sosial. Oleh karena itu penanganan penanggulangan kemiskinan di Kecamatan Kertek harus benar- benar membutuhkan suatu program dari pemerintah yang tepat pada sasaran. Sehingga Program Keluarga Harapan (PKH) muali dijalankan pada tahun 2015 di Kabupaten Wonosobo guna untuk merespon permasalahan kemiskinan, khususnya di Kecamatan Kertek. Dengan adanya Program Keluarga Harapan (PKH) diharapkan dapat membantu masyarakat miskin untuk ikut serta terhadap program $\mathrm{PKH}$ yang nantinya dapat memberikan dampak positif bagi kehidupan mereka terutama untuk meningkatkan kualitas hidup seperti kesehatan, pendidikan, dan kesejahteraan sosial, yang diharapkan dapat memutus rantai kemiskinan yang selama ini menherat rumah tangga miskin. Dengan demikian proses pengentasan kemiskinan melalui program PKH bukanlah proses yang mudah, melainkan sebuah proses yang membutuhkan pendekatan muali dari pendataan hingganpemutakhiran peserta, hingga dianggap benar- benar miskin dan layak menerima bantuan tersebut. Belajar pada tahun sebelumnya bahwa program penanggulangan kemiskinan, dalam kenyataanya sering menjumpai kondisi yang dirasa kurang membuahkan hasil dan kurang menguntungkan karena penanggulangannya yang bersifat jangka pendek dan tidak meningkatkan kualitas manusia, namun seharusnya program- program tersebut bisa meningkatkan kualitas manusia seperti meningkatkan pendidikan, kesehatan, dan kesejahteraan sosial, agar dapat keluar dari jeratan lingakaran setan kemiskianan.

Kabupaten Wonosobo terdiri atas 15 kecamatan yang terbagi lagi atas 29 keluarahan, dan 236 desa. Pusat pemerintahan berada di Kecamatan Wonosobo, adapun kecamatan di Kabupaten Wonosobo, sebagai berikut: Garung, Kalibawang, Kalikajar, Kaliwiro, Kejajar, Kepil, Kertek, Leksono, Mojotengah, Sapuran, Selomerto, Sukoharjo, Wadaslintang, Watumalang, dan Wonosobo. Dengan masing- masing bantuan sebagai berikut:

\section{Tabel 2}

\section{Data Penerima Manfaat Program Perlindungan Sosial Program Keluarga Harapan (PKH) Kabupaten Wonosobo} tahun 2019

\begin{tabular}{llcc}
\hline No & Nama & $\begin{array}{l}\text { Jumlah } \\
\text { Penduduk Miskin }\end{array}$ & Peserta PKH \\
\hline 1 & Garung & 4.149 & 4.026 \\
\hline 2 & Kalibawang & 1.371 & 1.377 \\
\hline 3 & Kalikajar & 4.483 & 4.333 \\
\hline 4 & Kaliwiro & 1.990 & 1.977 \\
\hline 5 & Kejajar & 3.690 & 3.573 \\
\hline 6 & Kepil & 4.892 & 4.659 \\
\hline 7 & Kertek & 5.617 & 5.452 \\
\hline 8 & Leksono & 1.661 & 1.582 \\
\hline 9 & Mojotengah & 3.773 & 3.539 \\
\hline 10 & Sapuran & 3.765 & 3.465 \\
\hline 11 & Selomerto & 1.941 & 1.821 \\
\hline
\end{tabular}




\begin{tabular}{llll}
\hline 12 & Sukoharjo & 1.307 & 1.297 \\
\hline 13 & Wadaslintang & 3.284 & 3.352 \\
\hline 14 & Watumalang & 3.204 & 3.156 \\
\hline 15 & Wonosobo & 2.673 & 2.583 \\
\hline & Total & 46.132 & 47.800 \\
\hline
\end{tabular}

Sumber: Dinas Sosial Kabupaten Wonosobo 2019

Berdasarkan tabel 2, jumlah penduduk miskin paling banyak di Kabupaten Wonosobo adalah Kecamatan Kertek dengan jumlah 5.617 jiwa, dan paling banyak penduduk yang menerima bantuan Prgram Keluarga Harapan (PKH) yaitu sebesar 5.452 jiwa. Dengan kualitas pendidikan yang masih rendah, kesehatan yang masih rendah serta kesejahteraan yang menurun. Dalam pengelolaan dan bantuan Program Keluarga Harapan (PKH) masih banyak masyarakat di Kecamatan Kertek yang belum mengelola bantuan dengan sebagaimana mestinya. Indikator permasalahan kesehatan, pendidikan, dan kesejahteraan sosial dapat tersajikan. Namun dari permasalahan tersebut peneliti menganggap sudah cukup alasan untuk melakukan penelitian terhadap fenomena kemiskinan. Untuk mencapai tujuan penelitian ini Program Keluarga harapan $(\mathrm{PKH})$ dalam bidang pendidikan, kesehatan, dan kesejahteraan sosial berupaya terus memotivasi Rumah Tangga Miskin (RTM) agar terus bekerja keras dalam memenuhi kebutuhan hidupnya. Program PKH di Kecamatan Kertek dinilai sudah berjalan sesuai dengan yang diharapkan, namun demikian hal tersebut tidak terlepas dari adanya hambatanhambatan. Salah satunya yaitu mengenai kevalidan data kelayakan peserta Program Keluarga Harapan (PKH) di Kecamatan Kertek, selain itu adanya koordinasi dari pihak yang terkait agar pelaksanaanya dapat menjaring kelompok sasaran yang tepat dan berjalan sesuai dengan rencana.

\section{LANDASAN TEORI}

Melihat dari sudut pandang spasial dan sektoral menurut Yulianto Kadji (2012) kemiskinan selalu dikaitkan dengan perdesaan, pertanian, sektor informal, dan status pekerjaan kelompok miskin. Sebagian besar penduduk miskin tinggal di pedesaan dengan orientasi pembangunan yang bias pada daerah perkotaan, usaha yang bersifat fomal dan komersial, serta fokus pada pulau jawa dinilai semakin mempersulit upaya percepatan pengentasan kemiskinan di Indonesia. Sejalan dengan Bappenas (2018), karakteristik miskin salah satunya adalah melihat kondisi geografis, yang tingkat kemiskinan tertinggi umumnya berada di wilayah pedesaan. Penduduk miskin di daerah pedesaan cenderung memiliki pendapatan dan daya konsumsi yang rendah, menderita kekurangan gizi, buta huruf, tinggi resiko terhadap kematian bayi, dan standar perumahan yang lebih rendah dibandingkan dengan daerah perkotaan.

Namun pada prinsipnya kemiskinan tersebut dapat menggambarkan kondisi ketiadaan kepemilikan dan rendahnya pendapatan, atau dilihat secara rinci dapat menggambarkan kondisi yang tidak dapat terpenuhinya kebutuhan dasar masyarakat itu sendir, seperti pangan, papan, dan sandang. Salah satunya yaitu definisi kemiskinan menurut BPS, yang menjelaskan bahwa kemiskinan dipandang sebagai ketidakmampuan dari sisi ekonomi untuk memenuhi kebutuhan dasar makanan dan bukan makanan yang diukur dari sisi pengeluaran (BPS, 2019).

Kemiskinan Ragnar Nurkse atau dikenal sebagai teori lingkaran setan kemiskinan (vicious circle of poverty) adalah suatu lingkaran yang merupakan rangkaian yang saling mempengaruhi satu dengan yang lainnya, sehingga menyebabkan suatu keadaan dimana negara akan tetap mengalami kemiskinan dan mengalami kesulitan dalam mencapai pembangunan yang lebih baik kedepannya (Nurdiansyah, 2016).

Upaya untuk menanggulangi kemsikinan pemerintah telah menerbitkan Peraturan Presiden Nomor 15 Tahun 2010, tentang Percepatan Penanggulangan Kemiskinan yang merupakan penyempurnaan dari Peraturan Presiden Nomor 13 Tahun 2009 tentang Koordinasi Penanggulangan Kemiskinan. Dalam Perpres tersebut diamanatkan untuk membentuk Tim Nasional Percepatan Penanggulangan Kemiskinan (TPN2K) di tingkat pusat yang keanggotaanya terdiri dari unsur pemerintah, masyarakat, dunia usaha, dan pemangku 
kepentingan lainnya. Sedangkan di provinsi dan kabupaten/ kota dibentuk Tim Koordinasi Penanggulangan Kemiskinan (TPKP) Provinsi dan Kabupaten/ Kota.

Melalui Tim Nasional Percepatan Penanggulangan Kemiskinan (TNP2K) telah mengklasifikasikan dalam tiga kelompok klaster, diantaranya yaitu:

1. Program- Program Penanggulangan Kemiskinan Klaster 1

Program- program Penanggulangan Kemiskinan Klaster 1 (satu) merupakan bantuan sosial terpadu berbasis keluarga yang bertujuan untuk mengurangi beban rumah tangga miskin melalui peningkatan akses terhadap pelayanan kesehatan, pendidikan, air bersih, dan sanitasi. Adapun Program- program dari Klaster 1 diantaranya: a) Program Keluarga Harapan (PKH); b) Bantuan Operasional Sekolah (BOS); c) Jaminan Keseharan Masyarakat (JAMKESMAS); d) Beras Untuk Keluarga Miskin (RASKIN); e) Bantuan Siswa Miskin (BSM)

2. Program- Program Penanggulangan Kemiskina Klaster II

Program Penanggulangan Kemsikinan Klaster II merupakan program penanggulangan kemiskinan berbasis pemberdayaan masyarakat miskin untuk terlibat dalam pembangunan yang didsarkan pada prinsip- prinsipnya, yang digunakan untuk memperbaiki kualitas kehidupan masyarakat miskin melalui pendekatan pemberdayaan yang bertujuan untuk memutus rantai kemiskinan dengan menggunakan potensi dan sumber daya yang dimiliki. Adapun jenis program pada Klaster II adalah Program Nasional Pemberdayaan Masyarakat (PNPM), Pengembangan Infrastruktur Sosial Ekonomi Wilayah (PISEW), Program Penyediaan Air Minum Berbasis Masyarakat (PAMSIMAS), dan Program Perluasan Dan Pengembangan Kesempatan Kerja/ Padat Karya Produktif.

3. Program- Program Penanggulangan Kemiskinan Klaster III

Program Penanggulangan Kemiskinan Klaster III merupakan program penanggulangan kemiskinan berbasis pemberdayaan usaha ekonomi mikro dan kecil, tujuan dari program ini yaitu untuk memberikan akses dan penguatan ekonomi bagi pelaku usaha berskala mikro dan kecil yang memberikan akses seluas- luasnya kepada masyarakat miskin untuk dapat berusaha dan meningkatkan kalitas hidup masyarakat dengan memberikan modal atau pinjaman dalam skala mikro. Program pada Klaster III ini adalah Kredit Usaha Rakyat (KUR) serta Kredit Usaha Bersama (KUBE).

Dari beberapa program penanggulangan kemiskinan diatas, salah satu program yang dijadikan objek penelitian oleh peneliti adalah Program Keluarga Harapan (PKH) yang berada pada Klaster I.

\section{Program Keluarga Harapan (PKH)}

Program Keluarga Harapan atau yang sering disebut dengan $\mathrm{PKH}$ adalah program asistensi sosial kepada rumah tangga yang memnuhi kualifikasi tertentu dengan memberlakukan persyaratan dalam rangka untuk mengubah perilaku miskin. Program tersebut merupakan program pemberian uang tunai kepada Rumah Tangga Sangat Miskin (RTSM) dan bagi anggota keluarga RTSM diwajibkan melaksanakan persyaratan dan ketentuan yang telah ditetapkan. Program ini secara internasional dikenal sebagai Program Conditional Cash Transfer (CCT) atau bantuan tunai bersyarat. Persyaratan tersebut dapat berupa kehadiran di fasilitas pendidikan misalnya bagi anak usia sekolah yaitu Fasilitas Layanan Pendidikan (FASDIK), ataupun kehadiran di Fasilitas Layanan Kesehatan (FASKES) misalnya bagi anak balita atau ibu hamil, selaian itu manfaat PKH juga untuk membantu penyandang disabilitas dan lanjut usia dengan mempertahankan taraf kesejahteraan sosialnya.

\section{METODOLOGI}

Metode yang digunakan dalam penelitian ini adalah metode kualitatif dengan metode analisis deskriptif. Penelitian kualitatif adalah suatu metode penelitian yang bersifat alamiah sesuai dengan pendapat Moleong (2016) ciri- ciri penelitian kualitatif adalah: (1) latar alamiah; (2) manusia sebagai instumen; (3) menggunakan metode kualtatif seperti wawancara, pengamatan, penelaahan dokumen; (4) analisis secara induktif; (5) adanya fokus peneltian, dll. 
Penelitian ini dilakukan di Kecamatan Kertek Kabupaten Wonosobo yang berlokasi di J Parakan No. 162 Kertek Wonosobo, yang dilaksanakan mulai bulan Desember 2019 sampai dengan Februari 2020. Subjek dalam penelitian ini adalah informan pengurus Program Keluarga Harapan yaitu PKH di Dinas Sosial Provinsi Jawa Tengah, Koordinator Unit Pelaksanaan Program keluarga Harapan (UPPKH) Kabupaten Wonosobo, Staf bagian perencanaan di BAPPEDA Kabupaten Wonosobo, Sekretaris Kecamatan Kertek, Pendamping PKH di Kecamatan Kertek kabupaten Wonosobo, dan Keluarga Penerima Manfaat di Kecamatan Kertek. Sumber penelitian terdiri dari : (a) data primer yaitu data yang diperoleh secara langsung, dalam penelitian ini data primer diperoleh dengan melalui wawancara dengan pihak- pihak terkait sesuai dengan permasalahan yang diteliti. Penelitian ini menggunakan data sekunder dan data primer. Data sekunder diperoleh dari berbagai instansi terkait seperti materi penelitian, data dari BPS, BAPPEDA, UPPKH Kabupaten Wonosobo. data sekunder adalah data penelitian yang diperoleh untuk melihat gambaran umum Implementasi PKH di Kecamatan Kertek melalui profil lembaga, buku referensi, artikel ilmiah dan pedoman PKH 2019. Data sekunder ini diperoleh dengan metode observasi yaitu dengan mengamati langsung dokumen-dokumen yang digunakan dalam pengumpulan data penelitian dan dokumetasi yaitu berupa data $\mathrm{PKH}$. Sumber data primer dalam peneltian ini adalah informasi yang diperoleh dari hasil wawancara dengan pegawai SKPD di Kecamatan Kertek.

Guna memperoleh data dilapangan dalam rangka mendeskripsikan dan menjawab permasalahan yang diteliti, maka data yang diperoleh dalam penelitian ini sebagai berikut: (a) observasi, jenis observasi yang digunakan dalam penelitian ini adalah observasi terus terang. Observasi ini dilakukan dengan pengamatan langsung ke kantor SKPD untuk mengamati pelaksanaan implementasi PKH di Kecamatan Kertek; (b) wawancara, wawancara dalam penelitian ini dilakukan kepada petugas DKPD dan Keluarga Penerima Manfaat (KPM) di Kecamatan Kertek; (c) dokumentasi, teknik ini digunakan untuk menganalisa dokumen-dokumen terkait implementasi PKH di Kecamatan Kertek.

Teknik analisis data dalam penelitian ini ada beberapa tahap diantaranya yaitu: (a) reduksi data, pada tahapan ini peneliti memilah dan memilih data $\mathrm{PKH}$ yang relevan. Data yang diperoleh dari UPPKH Dinas Sosial Kabupaten Wonosobo seagai bahan mentah dan diolah kembali dengan memfokuskan kemiskinan dan kehidupan pada KPM di Kecamatan Kertek; (b) penyajian data, dalam tahapan ini penyajian data dalam bentuk tema-tema singkat yang langsung diikuti dengan analisis setiap tema sehingga akhirnya diperoleh kesimpulan dari setiap informan $\mathrm{PKH}$; (c) menarik kesimpulan, setelah mendapatkan data dari hasil wawancara, observasi dan studi dokumentasi dengan melakukan penafsiran dan menganalisis secar kritis mengenai kemiskinan dan implementasi $\mathrm{PKH}$, hambatan dan solusi dalam kemiskinan kemudian ditarik kesimpulan hingga mencapai tujuan yang diharapkan.

\section{HASIL DAN PEMBAHASAN}

\section{Gambaran Umum Objek Penelitian Profil Kecamatan Kertek}




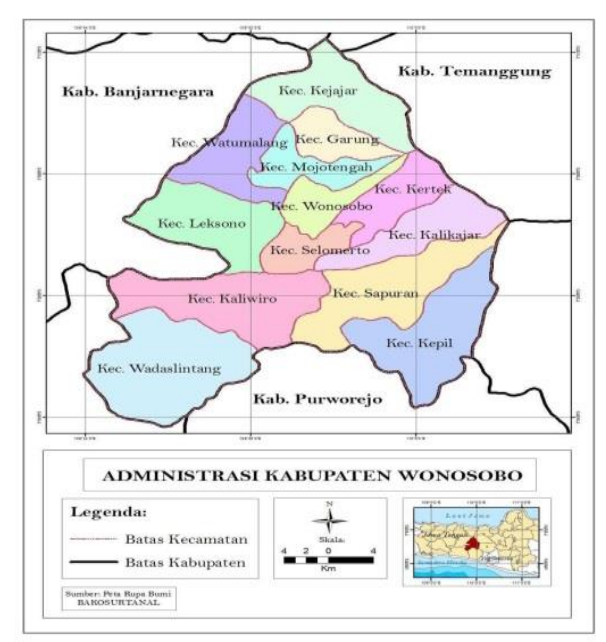

\section{Gambar 1 Peta Kabupaten Wonosobo 2018}

Kecamatan Kertek merupakan kecamatan yang berada di Kabupaten Wonosobo yang terletak di Provinsi Jawa Tengah. Kecamatan Kertek juga merupakan salah satu kawasan di Kabupaten Wonosobo yang memiliki daerah pegunungan. Terletak di sebelah timur ibukota Kabupaten Wonosobo, dengan jarak $9 \mathrm{~km}$ dari jalan jalur Kabuapten Temanggung, yang memiliki luas daerah $62,14 \mathrm{Km}^{2}$ atau $6,31 \%$ dari luas Kabupaten Wonosobo. Secara geografis, Kecamatan Kertek terletak pada 7018'40"- 7024'40" lintang selatan (LS) dan 109'93'30"$110^{\circ} 02^{\prime} 35^{\prime \prime}$ bujur timur (BT). Kecamatan Kertek berbatasan langsung dengan Kabupaten Temanggung di sebelah utara, di sebelah timur dengan Kecamatan Kalikajar, di sebelah selatan dengan Kecamatan Selomerto, dan di sebelah barat berbatasan dengan Kecamatan Wonosobo. Secara administratif, Kecamatan Kertek terdiri dari 19 desa dan 2 kelurahan yang terdiri dari Desa Sindupaten, Surengede, Bojasari, Kertek, Sumberdalem, Purwojati, Karangluhur, Ngadikusuman, Wringinanom, Sudungdewo, Bejiarum, Damarkasihan, Banjar, Tlogodalem, Pagerejo, Candimulyo, Purbosono, Candiyasan, Kapencar, dan Reco. Dengan desa terluas adalah Desa Candiyasan dan yang terkecil adalah Desa Banjar. Untuk lebih jelasnya dapat dilihat pada tabel berikut:

Tabel 3

Pembagian Wilayah Kecamatan Kertek Kabupaten Wonosobo

\begin{tabular}{clccc}
\hline No & \multicolumn{1}{c}{ Desa } & $\begin{array}{c}\text { Luas } \\
\left(\mathrm{Km}^{2}\right)\end{array}$ & $\begin{array}{c}\text { Presen- } \\
\text { tase } \\
(\%)\end{array}$ & $\begin{array}{c}\text { Jumlah } \\
\text { Penduduk }\end{array}$ \\
\hline 1 & Sindupaten & 1,63 & 2,62 & 3.860 \\
\hline 2 & Surengede & 1,60 & 2,58 & 3.836 \\
\hline 3 & Bojasari & 1,75 & 2,82 & 3.774 \\
\hline 4 & Kertek & 2,10 & 3,38 & 8.048 \\
\hline 5 & Sumberdalem & 1,05 & 1,69 & 4.151 \\
\hline 6 & Puwojati & 1,66 & 2,67 & 4.369 \\
\hline 7 & Karangluhur & 2,19 & 3,52 & 6.237 \\
\hline 8 & Ngadikusuman & 1,79 & 2,88 & 3.248 \\
\hline 9 & Wringinanom & 1,20 & 1,93 & 2.595 \\
\hline 10 & Sudungdewo & 1,71 & 2,75 & 3.662 \\
\hline 11 & Bejiarum & 1,58 & 2,54 & 3.652 \\
\hline 12 & Damarkasihan & 5,64 & 9,08 & 3.183 \\
\hline 13 & Banjar & 0,97 & 1,56 & 1.663 \\
\hline & & & &
\end{tabular}




\begin{tabular}{clccc}
\hline 14 & Tlogodalem & 1.44 & 2,32 & 2.287 \\
\hline 15 & Tlogomulyo & 4,38 & 7,05 & 1.859 \\
\hline 16 & Pagerejo & 5,36 & 8,63 & 5.539 \\
\hline 17 & Candimulyo & 4,13 & 6,63 & 6.795 \\
\hline 18 & Purbosono & 1,62 & 2,61 & 3.033 \\
\hline 19 & Candiyasan & 8,09 & 13,02 & 4.506 \\
\hline 20 & Kapencar & 6,33 & 10,19 & 5.735 \\
\hline 21 & Reco & 5,91 & 9,51 & 7.756 \\
\hline & Jumlah & $\mathbf{6 2 , 1 3}$ & $\mathbf{1 0 0}$ & $\mathbf{9 0 . 2 5 4}$
\end{tabular}

Sumber: Proyeksi penduduk menurut desa di Kecamatan Kertek tahun 2020

\section{Kemiskinan di Kecamatan Kertek}

Penelitian ini membuktikan bahwa permasalahan kemiskinan saat ini masih belum bisa di atasi oleh setiap negara, termasuk Indonesia. Salah satu Provinsi di Indonesia yang memiliki penduduk miskin cukup banyak adalah Provinsi Jawa Tengah dengan 35 Kabupaten/Kota. Berdasarkan Badan Pusat Statistik (BPS) Provinsi Jawa Tengah Tahun 2020 Kabupaten Wonosobo merupakan Kabupaten yang masuk kedalam 2 besar zona keparahan kemiskinan setelah Kabupaten Kebumen. Kemiskinan tersebut juga tersebar di seluruh kecamatan atau kelurahan di Kabupaten Wonosobo. Namun, tingkat kemiskinan tertinggi berada di Kecamatan Kertek.

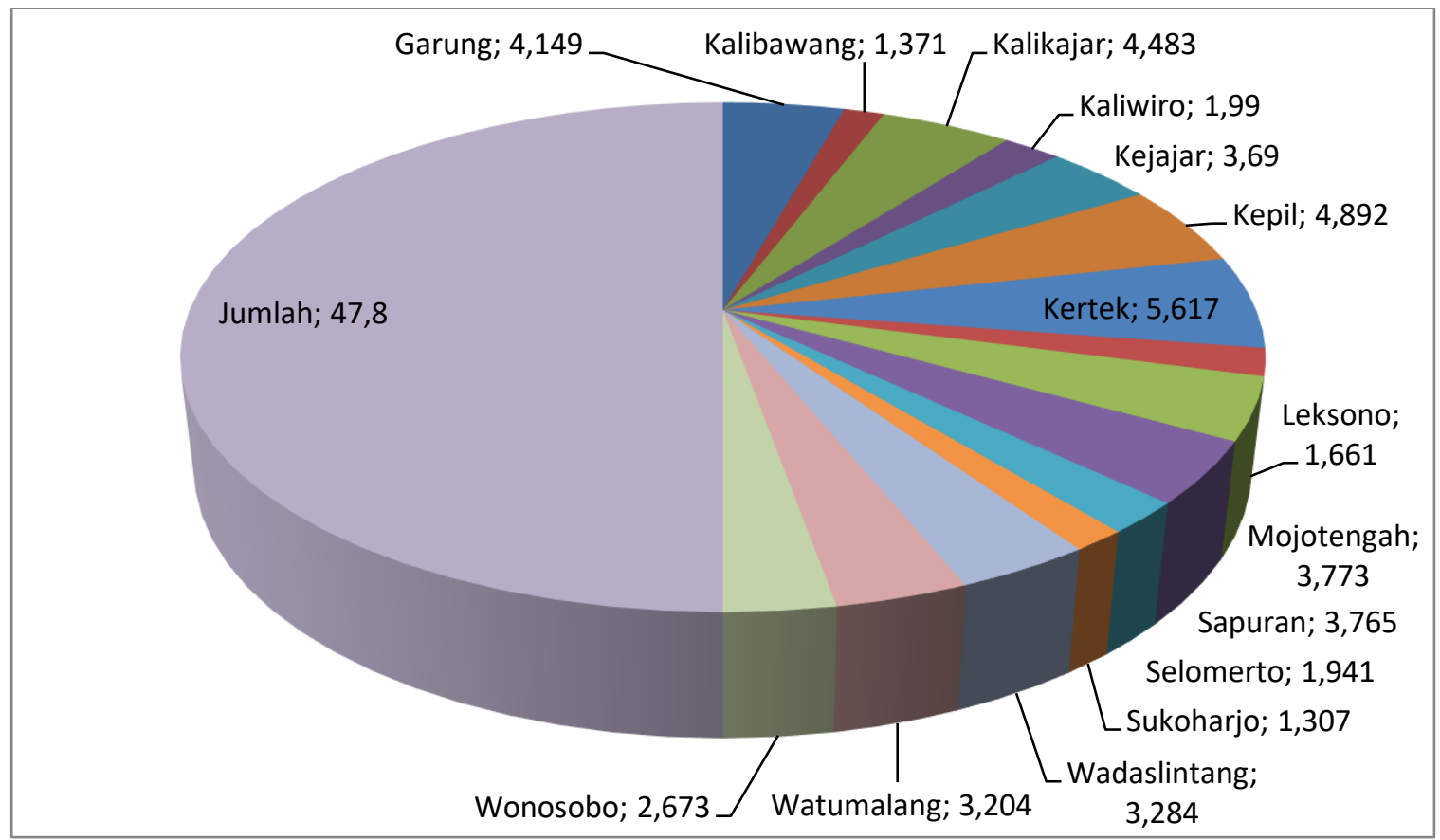

Sumber : Rekapitulasi Graduasi KPM Tahun 2019 Kab. Wonosobo

\section{Gambar 1 Jumlah Penduduk Miskin Menurut Kecamatan se-Kabupaten Wonosobo tahun 2019}

Dari Gambar 1. dapat dijelaskan bahwa Kecamatan Kertek merupakan Kecamatan yang paling banyak jumlah penduduk miskin, yaitu mencapai 5.617 jiwa. Kemiskinan di Kecamatan Kertek menjadi sorotan bagi pemerintah Kabupaten Wonosobo, untuk itu salah satu langkah 
untuk menanggulangi kemiskinan di kecamatan tersebut yaitu dengan memberikan bantuan Program Keluarga Harapan (PKH).

Berdasarkan pendapat Chambers (1996) dalam penelitian Slamet Agus (2013) dapat diketahui bahwa kemiskinan yang dialami oleh suatu rumah tangga sama dengan roda penggerak yang mundur dengan cepat yang sulit bahkan tidak mungkin untuk kembali dengan cepat sehingga rumah tangga miskin akan tetap miskin. Jika dikaitkan dengan pengentasan kemiskinan melalui PKH di Kecamatan Kertek sebagai udaha untuk merubah pada kondisi yang lebih baik untuk mendapatkan tingkat kesejahteraan. Masyarakat miskin Keluarga Penerima Manfaat (KPM) yang berada di Kecamatan Kertek lebih mengutamakan bantuan yang bersifat individu yang memperhatikan kondisi rill masyarakat miskin, bukan kondisi umum, masyarakat miskin membutuhkan kesejahteraan dalam rumah tangga, membutuhkan pendidikan bagi anakanak, membutuhkan kesehatan bagi Keluarga Penerima Manfaat (KPM), bantuan seperti itulah yang sedang dibutuhkan oleh masyarakat Kecamatan Kertek, ketidakberdayaan dalam melawan kemiskinan yang harus diperhatikan dan dibantu.

Berdasarkan penelitian yang dilakukan oleh Rusdarti \& Lesta Karolina (2013) kemiskinan disebabkan karena keadaan kepemilikan sumber daya yang tidak merata, kemampuan masyarakat yang tidak seimbang, dan ketidaksamaan kesempatan dalam berusaha dan memperoleh pendapatan.

\section{Profil Keluarga PKH di Kecamatan Kertek Kabupaten Wonosobo}

Keluarga Penerima Manfaat (KPM) merupakan keluarga yang menerima bantuan sosial bersyarat yang masuk kedalam data penerimaan Program Keluarga Harapan (PKH). Sebagai sebuah program bantuan sosial bersyarat, PKH membuka askes keluarga miskin terutama ibu hamil dan anak untuk memanfaatkan berbagai fasilitas layanan kesehatan (faskes) dan fasilitas layanan pendidikan (fasdik) yang tersedia di sekitar mereka. Manfaat PKH juga mulai didorong untuk mencakup penyandang disabilitas dan lanjut usia dengan mempertahankan taraf kesejahteraan sosialnya sesuai dengan amanat konstitusi dan Nawacita Presiden RI.

Kehidupan KPM di Kecamatan Kertek didominasi oleh permukiman yang padat penduduk. Mayoritas penduduknya bekerja sebagai petani dan buruh tani yang setiap harinya harus bekerja. Upah dari hasil pekerjaan tersebut masih belum bisa memenuhi kebutuhan keluarganya. Oleh sebab itu banyak keluarga yang kurang mampu secara ekonomi. Dampak dari perekonomian tersebut mengakibatkan angka partisipasi pendidikan, kesehatan, dan kesejahteraan sosial di Kecamatan Kertek rendah. Selain itu letak geografis Kecamatan Kertek yang terdapat di lereng Gunung mengakibatkan keterbatasan akses untuk memenuhi ketiga komponen dalam $\mathrm{PKH}$.

Kepadatan penduduk menimbulkan banyaknya rumah yang tidak layak huni seperti: ukuran rumah yang kecil dan sempit yang dihuni oleh dua kepala keluarga, selain itu masih banyak KPM yang tidak memiliki saluran pembuangan akhir manusia, sehingga sanitasi di Kecamatan Kertek rendah. Rata- rata KPM di Kecamatan Kertek banyak didominasi oleh bantuan komponen pendidikan, karena pendidikan di Kecamatan Kertek rendah.

Kehidupan keluarga penerima manfaat di Kecamatan Kertek hingga saat ini masih terkendala dengan belum adanya saluran sanitasi yang baik. Selama ini masyarakat di Kecamatan Kertek banyak yang tidak memiliki kamar mandi sendiri untuk menunjang kebutuhan dasar hidupnya. Setiap harinya harus menumpang di kamar mandi milik bersama, hal tersebut biasanya terjadi pada keluarga yang tergolong miskin.

Sebagian masyarakat juga bekerja sebagai buruh pemecah batu di lereng Gunung Sindoro dengan pendapatan yang tidak lebih dari Rp500.000 perbulan. Hal ini menyebabkan sebagian masyarakat tidak bisa membangun kamar mandi atau setidaknya jamban sederhana. Hidup serba kekurangan tanpa adanya jamban dan menumpang mandi di WC milik orang lain ini sudah biasa dirasakan pada masyarakat Kertek. Untuk memenuhi kebutuhan MCK, masyarakat yang tidak mempunyaki kamar mandi harus menuju ke mata air yang jaraknya sekitar $1 \mathrm{~km}$ dari tempat tinggal mereka dan berbagi bersama masyarakat lainnya. 


\section{Implementasi Bantuan Bersyarat Bagi Keluarga Pkh}

Berdasarkan hasil temuan menurut Muhammad Arif (2018), bahwa tingat kemiskinan di Kabupaten Wonosobo dari tahun 2015- 2017 belum sepenuhnya teratasi, dikarenakan jumlah Keluarga Penerima Manfaat (KPM) yang sangat banyak belum sebanding dengan jumlah pendamping yang tersedia sehingga masih terjadi overload. Namun menurut temuan hasil pengamatan dan wawancara peneliti, di Kecamatan Kertek Kabupaten Wonosobo perlahan mengalami penurunan setiap tahunnya. Hal ini membuktikan bahwa segala bentuk program pemerintah berjalan secara maksimal termasuk Program Keluarga Harapan (PKH). Penyaluran Program Keluarga Harapan $(\mathrm{PKH})$ bagi kelompok masyarakat miskin bertujuan untuk mengurangi beban pengeluaran masyarakat miskin. Dengan berkaca melalui konsep pemberdayaan dalam membangun masyarakat (community development) agar dapat memperbaiki kualitas kehidupan serta mengembangkan segala kemampuan yang dipunyai oleh masyarakat Keluarga Penerima Manfaat (KPM).

Salah satu program sosial yang sedang dijalankan dan dikembangkan oleh Pemerintah adalah Program Keluarga Harapan. Program Keluarga Harapan merupakan program yang memberikan bantuan tunai bersyarat kepada rumah tangga sangat miskin (RTSM) yang sekarang mengalami perubahan pada tahun 2019 menjadi Keluarga Penerima Manfaat (KPM). Sebagai imbalannya Keluarga Penerima Manfaat diwajibkan untuk memenuhi persyaratan yang terkait dengan upaya peningkatan kualitas ol,sumber daya manusi, yaitu pendidikan, kesehatan dan kesejahteraan keluarga. Tujuan utama Program Keluarga Harapan adalah membantu mengurangi kemiskinan dengan cara meningkatkan kualitas sumber daya manusia pada kelompok masyarakat sangat miskin dengan memberikan bantuan berupa uang tunai.

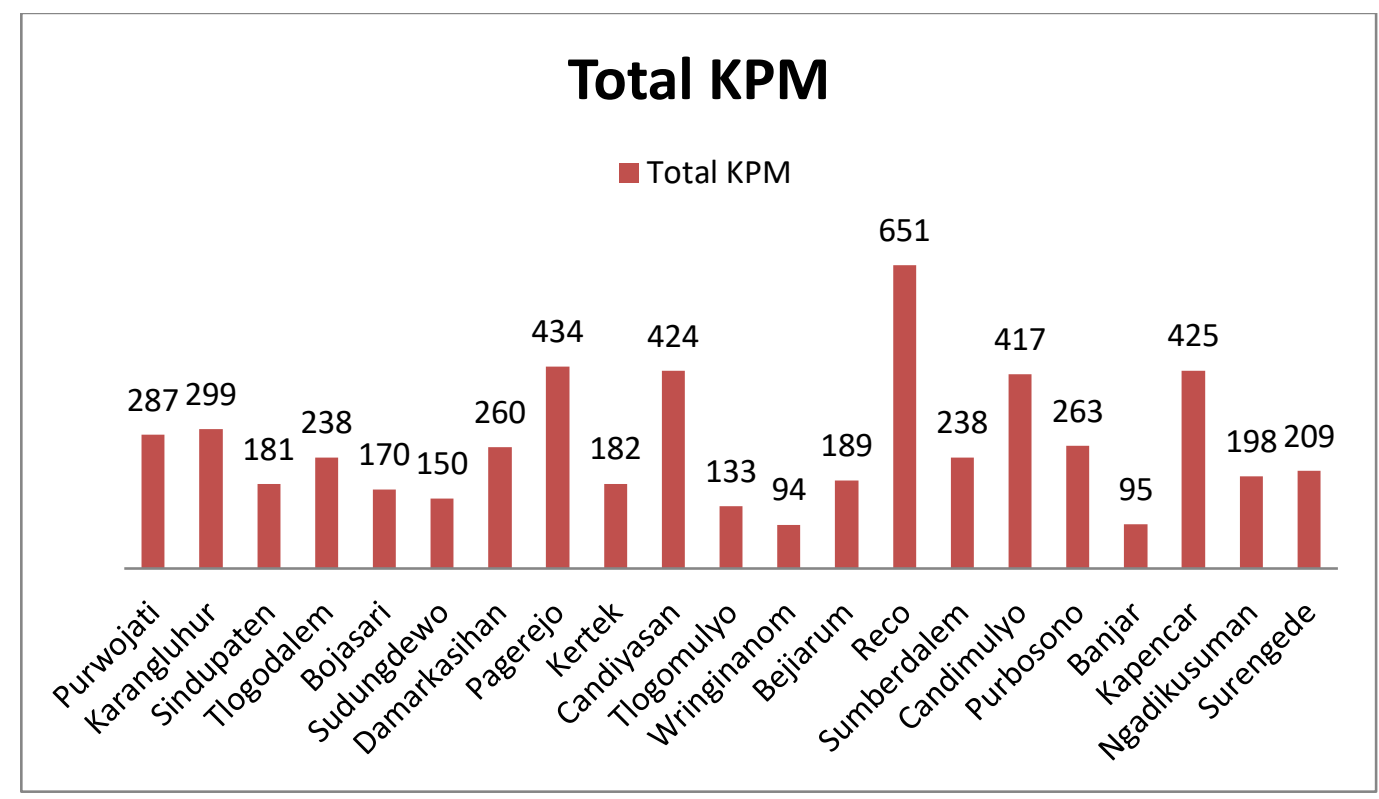

Sumber: Data alokasi penerimaan KPM

Dinas Sosial Provinsi Jawa Tengah 2019

\section{Gambar 2 Jumlah penerima KPM per-Desa Kecamatan Kertek Kabupaten Wonosobo September 2019}

Gambar 2. dapat dijelaskan bahwa total Rumah Tangga (RUTA) yang mendapatkan bantuan PKH di Kecamatan Kertek yaitu 5.452 jiwa, merupakan kecamatan yang paling banyak menerima bantuan Program Keluarga Harapan (PKH). Padahal sebelumnya pada tahap ke tiga penerima bantuan Program Keluarga Harapan (PKH) di Kecamatan Kertek sebesar 5.357 jiwa. Hal itu merupakan penambahan KPM pada tahun yang sama yaitu tahun 2019 (Dinsos Provinsi Jawa Tengah 2019).

Implementasi program bantuan tunai bersyarat atau Program Keluarga Harapan (PKH) 
di Kecamatan Kertek Kabupaten Wonosobo yang memfokuskan pada masyarakat miskin yang harus menerima program- program bantuan dari pemerintah dimana masyarakat telah benarbenar dalam keadaan tidak mampu dan harus menerima bantuan menurut teori pendekatan sumber daya dan hak yang dikemukakan oleh Armantya Sen (1981: 19). Dimana dalam teori tersebut membahas kemiskinan disebabkan karena ketidakberdayaan masyarakat untuk memenuhi kebutuhan hidupnya, selain itu, dalam konsep ini dapat dijelaskan bahwa kemiskinan tidak hanya berhubungan dengan ketidakmampuan seseorang dalam bekerja, tetapi juga berkaitan dengan hak- hak yang terlindungi, serta hilangnya kesempatan untuk mendapatkan harga yang layak untuk produk yang dihasilkan atau tenaga yang diberikan, atau hilangnya kesempatan untuk memperoleh bantuan, subsidi, dan program- program dari pemerintah, seperti Program Keluarga Harapan (PKH).

Kemudian secara teknis dari proses pelaksanaan Program Keluarga Harapan (PKH) di Kecamatan Kertek sudah sesuai dengan aturan yang berlaku. Namun, dalam kenyataanya di lapangan masih belum maksimal dikarenakan banyak masyarakat miskin yang masih belum menerima PKH akibat data yang kurang eligible. Sehingga implmentasi Program Keluarga Harapan $(\mathrm{PKH})$ di Kecamatan Kertek dapat dikatakan masih belum berjalan seperti yang diharapkan. Karena pada saat proses penyaluran sebagian besar aparat desa belum sepenuhnya melaksanakan pendataan terhadap pelaksanaan program.

Hal tersebut senada dengan temuan Shella Yulia Rosalina (2018) yang menganggap bahwa implementasi Program Keluarga Harapan $(\mathrm{PKH})$ belum berjalan seperti yang diharapkan dengan melihat masih banyak Keluarga Penerima Manfaat (KPM) yang belum menerima Program Keluarga Harapan (PKH) secara maksimal, karena keterbatasan pendamping dalam mendata masyarakat miskin. Selain itu penelitian yang dilakukan oleh Simanjuntak Agnes $P$, Rusdarti, dan Prasetyo P (2019) menggap bahwa implementasi PKH belum dilaksanakan secara optimal dikarenakan kelayakan program keluarga harapan yang dianggap tidak termasuk keluarga miskin, sementara pada saat yang sama terdapat orang yang dianggap orang miskin yang telah dieliminasi sebagai peserta dalam program keluarga harapan. Hal ini dikarenakan kesejahteraan di Kabupaten Brebes sangat rendah.

\section{Kendala dalam Pemberian Bantuan Bersyarat di Kecamatan Kertek Kabupaten Wonosobo}

Kendala dalam pemberian bantuan PKH di Kecamatan Kertek salah satunya yaitu kurang pemahaman rumah tangga sangat miskin terhadap sanksi yang diberikan akibat pelanggaran yang dilakukan oleh peserta $\mathrm{PKH}$. hal ini karena pada saat pengumpulan data persyaratan bantuan PKH masih banyak yang mengalami keterlamatan. Berdasarkan hasil temuan menurut Muhammad Arif (2018), bahwa tingat kemiskinan di Kabupaten Wonosobo dari tahun 2015- 2017 belum sepenuhnya teratasi, dikarenakan jumlah Keluarga Penerima Manfaat (KPM) yang sangat banyak belum sebanding dengan jumlah pendamping yang tersedia sehingga masih terjadi overload.

Kendala lain dalam pelaksanaan program ini adalah adanya data yang tidak benar yang dilakukan oleh masyarakat yang mengaku menjadi orang miskin untuk mendapatkan dana PKH tersebut. Selain itu bentuk tanggung jawab dari pemerintah yang kurang ikut andil dalam program penanggulangan kemiskinan di Kabupaten Wonosobo khususnya di Kecamatan Kertek. Selain itu disposisi dalam Implementasi Program Keluarga Harapan (PKH) dalam upaya penanggulangan kemiskinan pada Kecamatan Kertek mengenai sikap dan tugas aparatur Dinas Sosial, pendamping PKH dan Peserta PKH secara umum sudah baik, hanya saja ada beberapa peserta $\mathrm{PKH}$ yang kurang baik dari sisi kerjasama dan tanggungjawab.

Kendala selanjutnya yaitu permasalahan pendampingan dilihat dari jumlah dan data klien, pada program PKH di Kecamatan Kertek seorang pendamping harus mendampingi satu desa satu pendamping, hal itu dirasa kuang efektif karena terdapat jumlah penduduk yang melebihi batas dengan didampingi oleh satu orang pendamping saja. Kurangnya jumlah pendamping juga menjadi kendala yang cukup berarti untuk menghadapi jumlah KPM yang sedemikian banyaknya, apalagi dengan mempertimbangkan jarak dan kondisi desa para penerima bantan yang berbeda-beda.

Secara umum, hambatan-hambatan dalam pelaksanaan PKH di Kecamatan Kertek lebih 
bersifat teknis. Adapun kendala yang dihadapi salah satunya yaitu dalam proses graduasi, masih banyak KPM yang enggan untuk keluar secara sukarela. Para KPM masih sulit diarahkan keluar padahal dari segi kebutuhan dan ekonomi sudah layak di proses graduasi mandiri. Adanya graduasi mandiri KPM merupakan tolok ukur keberhasilan proses pendampingan dan terciptanya tujuan pelaksanaan Pertemuan Peningkatan Kemampuan Keluarga (P2K2). Kurangnya motivasi yang dimiliki oleh KPM juga merupakan kendala bahwa bantuan tersebut hanya bersifat sementara

\section{KESIMPULAN}

Program Keluarga Harapan (PKH) mempunyai tiga komponen yaitu pendidikan, kesehatan, dan kesejahteraan sosial. Rendahnya tingkat pendidikan Keluarga Penerima Manfaat (KPM) berpengaruh pada jenis pekerjaan dan penghasilan yang diperoleh juga rendah, sehingga berpengaruh kurang baik terhadap kemampuan KPM dalam memenuhi kebutuhan kesehatan dan pendidikan. Bantuan PKH berkontribusi terhadap kesejahteraan KPM, khususnya mampu mereduksi kekurangan kualitas dan kuantitas pangan (kesehatan). Berdasarkan data dan hasil penelitian di atas, bantuan sosial PKH dapat mempengaruhi pola konsumsi KPM ke arah yang lebih baik. Dapat diartikan bahwa bantuan PKH mampu merespon kemiskinan terhadap kekurangan kebutuhan konsumsi, kesehatan, pendidikan hingga Keluarga Penerima Manfaat (KPM) cenderung lebih sejahtera, meskipun terdapat variasi dalam

\section{DAFTAR PUSTAKA}

Adisanjaya, S. (2016). Program Keluarga harapan (PKH): Antara Perlindungan Sosial dan pengentasan Kemiskinan. Prosiding KS: Riset \& PKM, Vol. 4 No. 1 Hal. 1-140.

Amartya Sen. (1981). Demokrasi Bisa Memberantas Kemiskinan. Bandung. Penerbit Mizan.

Aan Komariah, Djam'an Satori. (2014). Metodologi Penelitian Kualitatif. Bandung: Alfabeta.

Bakhtiar, Ahmad. (2015). Implementasi Program Keluarga harapan Sebagai Upaya Penanggulangan Kemiskinan di Kecamatan Berbah Sleman Tahun 2013. Jurnal IImu Pemerintahan \& Kebijakan Publik, Vol. 2 No. 2. Yogyakarta: Universitas Muhamadyah Yogyakarta

Blanden, J. and Gibbons, S. (2006). The Pertsistence of Poverty Across Generations a View from two British Cohorts. Bristol: The Policy Press.

Bangun, Deylia C. (2016). Peran Program Keluarga Harapan (PKH) Dalam Meningkatkan Partisipasi Wajib Belajar 9 Tahun Bagi Anak Rumah Tangga Sangat Miskin (RTSM) di Kecamatan Sooko Kabupaten Mojokerto. Jurnal Paradigma, Volume 04 Nomor 01. Universita Negeri Surabaya.

Bank, W. (2007). Era Baru dalam Pengentasan Kemiskinan di Indonesia. Jakarta: The World Bank Office Jakarta.

Bowles, Samuel. (2006). Povert Traps. America

BPS. (2018). Data dan Informasi Kemiskinan Kabupaten/ Kota Tahun 2018. Wonosobo: BPS Kabupaten Wonosobo. 
Cahyono, S. A. (2018). The Action Step Of Expected Family Program: The Contribution of Expected family Program to the Welfare Improvement of Beneficiary Family. Balai Besar Penelitian dan Pengembangan Pelayanan Kesejahteraan Sosial , 1-3.

Chambers, Robert. (1996). PRA (Participatory Rular Appraisal), Memahami Desa Secara Partisipatif. Kansius: Yogyakarta.

Hendratno. (2010) Pengaruh Program Keluarga Harapan (PKH) terhadap Cakupan Imunisasi, Pemerikasaan Kehamilan, Angka Partisipasi Sekolah Dasar dan Sekolah Lanjutan Tingkat Pertama, dan Konsumsi Rumah Tangga. Tesis Online. Http://lib.ui.ac.id/file\%3File\%3Ddigital/203333967-T\%232032763-

Hendratno.pdf\&sa=U\&ved=0CasQfjAAahUKEwiu4sa6zKzIAhXJLYgKHWDwAPE\&usg= AFJCNHfXd7.

Https://amp.kompas.com/regional/read/2017/11/01/19292001/naik-87-persen-ump-jawatengah-2018-menjadi-rp-1486065.

Https://www.bappenas.go.id/files/6915/6082/6584/Analisis Wilayah dengan kemiskinan Ting gi - BAPPENAS.pdf.

Http://staffnew.uny.ac.id/upload/132304482/pendidikan/PEMIKIRAN+PENDIDIKAN+PAULO+F REIRE.pdf

Keluarga, D. J. (2019). Rangkuman Informasi Program Keluarga Harapan (PKH) 2019. Jakarta Pusat: Direktorat Jenderal Perlindungan dan Jaminan Sosial, Kementrian Sosial.

Michael P. Todaro, S. C. (2011). Pembangunan Ekonomi. Jakarta: Erlangga.

Moleong, Lexy. J. (2016). Metodologi Penelitian Kualitatif Edisi Revisi. Bandung: PT. Remaja Rosdakarya.

Nurdiansyah. (2016). Analisis Faktor-faktor yang Mempengaruhi Kemiskinan di Karisidenan Besuki dan Lumajang Tahun 2008-2013. UNEJ PRESS.

Nurkse, Ragnar. (1953). Problems of Capital Formation in Underdevoloped Countries.Oxford: Oxford University Press.

Simanjuntak, Agnes P., Rusdarti dan P. Eko Prasetyo (2019). The Implementation of Hope Family Program (PKH) in Poverty Prevention Effort in Kluwut Village Bulukumba District Brebes Regency. Journal of Economic Education, 12-21.

Statistik, B. R. (2018). Profil Kemiskinan di Provinsi jawa Tengah September 2018. BPS Provinsi Jawa Tengah 2018.

Rusdarti, R., \& Sebayang, L. K. (2013). Faktor-Faktor Yang Mempengaruhi Tingkat Kemiskinan di Provinsi Jawa Tengah. Jurnal Economia, 9(1), 1-9. 
